IJCCS (Indonesian Journal of Computing and Cybernetics Systems)

Vol.13, No.2, April 2019, pp. 105 116

ISSN (print): 1978-1520, ISSN (online): 2460-7258

DOI: $10.22146 / \mathrm{ijccs} .35794$

\title{
Classification of Human Weight Based on Image
}

\author{
Shofwatul 'Uyun*', Toni Efendi' \\ ${ }^{1,2}$ Program Studi Teknik Informatika, Fakultas Sains dan Teknologi \\ Universitas Islam Negeri Sunan Kalijaga, Yogyakarta, Indonesia \\ e-mail : ${ }^{* 1}$ shofwatul.uyun@uin-suka.ac.id, ${ }^{2}$ mail.toniefendi12@ gmail.com
}

\begin{abstract}
Abstrak
Klasifikasi berat badan manusia dapat ditentukan berdasarkan body mass index. Body mass index dapat dihitung secara matematis dengan membagi tinggi badan dengan kuadrat berat badan. Menurut peneliti hal ini kurang praktis sehingga perlu dibuat sebuah alat yang dapat digunakan untuk menentukan berat badan ideal secara lebih praktis. Salah satu caranya dengan menggunakan kamera smartphone android. Kamera tersebut digunakan untuk mengambil citra tubuh manusia. Kemudian citra diolah menggunakan pengolahan citra digital dan dengan menggunakan algoritma tertentu, maka dapat disimpulkan tentang kategori berat badan ideal seseorang tersebut. Data yang digunakan pada penelitian ini adalah foto manusia, berat badan dan tinggi badan. Terdapat empat tahapan untuk mengetahui berat dan tinggi badan berdasarkan citra. Pertama, melakukan analisis terhadap perhitungan rumus turunan dengan pendekatan rumus tabung. Kedua, analisis penggunaan algoritma deteksi tepi. Ketiga, melakukan konversi satuan dan keempat mengusulkan beberapa algoritma untuk menghitung tinggi dan berat badan yang digunakan untuk menentukan berat badan ideal. Hasil evaluasi menunjukkan bahwa Algoritma C ( menghitung lebar objek dimulai dari posisi tinggi citra yang menyesuaikan dengan setengah dari tinggi objek dalam citra) memiliki hasil terbaik. Algoritma ini menghasilkan nilai prosentase rata-rata selisih penyimpangan sistem sebesar 1,85\% terhadap tinggi badan dan 8,87\% terhadap berat badan. Sedangkan tingkat akurasi sistem dalam menentukan berat badan ideal telah mencapai 78,7\%.
\end{abstract}

Kata kunci-Berat Badan Manusia, Citra, Deteksi Tepi, Body Mass Index.

\begin{abstract}
Classification of human weight can be determined by body mass index. The body mass index can be calculated by dividing the height by the square of the body weight. According to researchers, this is less practical, so it needs to make a tool that can be used to determine ideal body weight more practically. One way is to use an Android smartphone camera. The camera is used to capture the image of the human body. Then the image is processed by using digital image processing and by using certain algorithms, so it may conclude the person's ideal weight category. The data used in this study are human photos, body weight and height. There are four stages to determine the weight and height based on the image. First, performing an analysis of the calculation of the derived formulas. Second, analyzing the edge detection algorithm. Third, conducting unit convertion, and fourth, proposing several algorithms to calculate the height and weight used to determine the ideal body weight. The results of the evaluation show that Algorithm $C$ (measuring the width of an object starting with the height of the image adjusting half of the height of the object in the image) is the best algorithm with deviation value of $1.85 \%$ of the height and $8.87 \%$ of the weight, while the system accuracy rate in determining the ideal body weight has reached $78.7 \%$.
\end{abstract}

Keywords - human weight, Image, edge detection, body mass index

Received May 24 $4^{\text {th }}$ 2018; Revised Jan 31 ${ }^{\text {th }}$ 2019; Accepted April 22 $2^{\text {th }}, 2019$ 


\section{INTRODUCTION}

Human weight can be classified into four categories those are thin, ideal, fat and obese. Ideal category is everyone's dream because it is positively correlated with health. To find out the ideal body weight, first one must measure the ideal weight using the convensional formula, then calculate the ideal body weight by using the Body Mass Index (BMI) formula. However, there is no tool that can be used to determine the ideal body weight practically, which makes many people not know and not care about the condition of their weight eventhough the body health is also influenced by the weight. According to World Health Organization (WHO) in 2014, there are more than 1.9 billion adults over the age of 18 in the world who are overweight, while more than 600 million people in the world are obese. Excessive weight gain that causes obesity has an adverse effect on health among them, increasing the risk of complications of heart disease, diabetes, high blood pressure, cholesterol, and other diseases. Therefore, to get a more practical way of determining the weight category, then in this study a tool will be developed using an Android smartphone camera. The camera will be used to take a person's body image. Furthermore, the image will be processed using a digital image processing to obtain some information that is useful in determining a person's weight category. The accuracy of selection of digital image processing techniques greatly affects the level of system accuracy. There are several ways to do to process the image, one of which is by using edge detection. Edge detection is a process in digital image processing to know the edge of the object in the image in order to obtain useful information from the image. There are several methods that are usually used to do edge detection, such as Robert, Sobel, Prewitt, and Canny, But, Canny is the best edge detection method for edge detection. In Research [1] Digital image processing is used to determine the weight of cow from image acquisition. This study is focused on segmentation and image processing of cows to get the best edge detection from several preprocessing scenarios. The results of the study conclude that scenario 3 (median blur and canny) has the best results with MSE values of 230,051 and PSNR of 24,524 db. Then research [2], which is the second stage of research [1] is focused on the selection of the formula for determining the weight of cow and proposed algorithms to determine the weight of cow from image acquisition. The results of image calculation are not different significantly with MAE (Mean Absolute Error) that is equal to $8.15 \%$ and $4.10 \%$ for body length and chest circumference, respectively. Digital image processing application that has been built is able to know the weight of cow with MAE (Mean Absolute Error) that is equal to $8.97 \%$ towards Modification/Lambourne formula. In research [3] it has developed a system for calculating human body weight using human body image. First, the process of cropping image is adjusted to the human body shape, then it uses the formula of body mass index to determine the ideal body weight. In research [4] it has successfully created a digital image processing system that can be used to determine the ideal body weight using edge detection. Image processing can also be used to determine the maturity level of salak pondoh with mature, moderate, and crude classification [5]. From research[5] it has obtained an accuracy of $92 \%$ if using backpropagation algorithm and $93 \%$ if using $\mathrm{K}$ Nearest Neighbor algorithm, so it can be concluded that the use of digital image processing system to classify the maturity level of salak pondoh in the tree is accurate. Based on several previous studies it can be seen that digital image processing can be used to calculate cow weight and maturity level classification from salak pondoh, so it is possible to use digital image processing to determine body weight categories in humans. Therefore, this study has developed a tool that can be used to classify human weight based on images taken by Android smartphone's camera.

IJCCS Vol. 13, No. 2, April 2019: $105-116$ 


\section{METHODS}

\subsection{Research Data}

The sample data used in the study are 47 people, those are 10 thin people, 25 people with ideal weight, 6 fat people and 6 obese people. The example of the sample data is shown in Table 1.

Table 1 Examples of sample data

\begin{tabular}{|c|c|c|c|c|c|}
\hline No. & Height $(\mathrm{cm})$ & Weight $(\mathrm{kg})$ & Width $(\mathrm{cm})$ & Shoulder height $(\mathrm{cm})$ & Age (year) \\
\hline 1. & 167 & 58 & 55 & 142 & 21 \\
\hline 2. & 166 & 49 & 52 & 136 & 17 \\
\hline 3. & 170 & 54 & 47 & 140 & 17 \\
\hline
\end{tabular}

\subsection{Design and Algorithm}

The research method used is a basic research method that is predictive. The steps used in this study are as follows:

1. Preparation

Preparation is to prepare a room that will be used as a place of taking photos of the respondents, plain color cloth as photo background, smartphone camera, tripod, scales, measuring height, cloths meter, ruler, scissor, duct tape, pencil and book to write the measurement result.

2. Image Acquisition and Body Measurement

Image acquisition is conducted by taking pictures of the human body using the camera Xiomi Redmi 2 with 8 mega pixel camera resolution. This process is conducted from a distance of $250 \mathrm{~cm}$ to the object and the camera's high distance about $110 \mathrm{~cm}$. The research objects wear clothes with plain colors that are different from the background color. The body position is standing perpendicular to the camera without wearing footwear, and the heel position of the crumpled foot is opened about $45^{\circ}$. After the picture has been taken, then the respondent measured his height, then weighed and measured his body width and shoulder height of the foot. The measurement results are recorded using stationery.

3. Calculation of Derived Formula

To calculate the ideal body weight, people usually use a conventional calculation formula like formula (1).

Ideal weight $=($ height -100$) \times 90 \%$

While, in this case the human body is assumed to be an elliptical tube [6]. The formula (2) is used to calculate The Surface Area of Tube. To calculate The Surface Area of Tube, first you should know about the height and width of the tube, the value is obtained from the height and width of the object in the image. The result of calculation of The Surface Area of Tube is then considered as a result of the calculation of the surface area of the human body.

Surface Area of Tube $=\left(\left(\frac{a, 14}{2}\right) \times(a \times b)\right)+\left(\left(\left(\frac{a, 14}{2}\right) \times(a+b)\right) \times t\right)$

From formula (2) by multiplying some other parameters, it has produced a new formula of body surface area (BSA) like formula (3).

BSA $\left(\mathrm{m}^{2}\right)=\left(\left(\frac{a, 14}{2}\right) \times((\mathrm{axb})+((\mathrm{a}+\mathrm{b}) \mathrm{xt}))\right) \times(\text { tpixel })^{2} \mathrm{xkx} 0,0001$

$\mathrm{b}$ is the width of object and $t$ is the height of object. Formula (4) and (5) are used to calculate the width and height of object.

Width of Object $=$ (pixel width) $\mathrm{x}$ (tpixel) 
Height of Object $=$ (pixel height) $\mathrm{x}$ (tpixel)

Formula (6) is used to calculate the tpixel.

Pixel $=\frac{\text { Height }(\mathrm{cm})}{\text { Height of Object (pixel) }}$

Of all calculated data samples in this study, it should be determined that tpixel is equal to 0.33 $\mathrm{cm} / \mathrm{px}$. After the value of tpixel is known then the calculation of BSA formula can be calculated. Furthermore, The BSA value is used in calculating the mosteller formula (7) to get the human body weight.

$$
\text { Weight }=\frac{\text { (BSA x BSA) } \times 3600}{\text { height }(\mathrm{cm})}
$$

4. Determination of Multiplier Factor (k)

The multiplier factor $(k)$ is a constant or value used to reduce the difference between the weight of the calculation of derived formula compared with actual weight. The multiplier factor (k) was obtained using formula (8).

$$
\mathrm{k}=\frac{\sqrt{\frac{\text { actual weight } x \text { actual height }}{3600}}}{\text { BSA }}
$$

The result of calculation from all of sample data has obtained the multiplier factor $(k)$ value that is equal to 1.0023 .

5. Preprocessing

Preprocessing is a step to reduce the noise from an image and image softening in order to obtain a better and cleaner image. In this research it proposes five preprocessing scenarios as shown in Table 2 and The sample data of SNR value for each preprocessing scenario as shown in Table 3.

Table 2 The preprocessing scenario is used

\begin{tabular}{|c|l|}
\hline Scenario & \multicolumn{1}{|c|}{ Preprocessing } \\
\hline Scenario 1 & Canny \\
\hline Scenario 2 & Median Blur + Canny \\
\hline Scenario 3 & Sharp + Canny \\
\hline Scenario 4 & Median Blur + Sharp + Canny \\
\hline Scenario 5 & Sharp + Median Blur + Canny \\
\hline
\end{tabular}

Table 3 Sample data of SNR value for each preprocessing test scenario

\begin{tabular}{|c|c|c|c|c|c|}
\hline \multirow{2}{*}{$\begin{array}{c}\text { Image } \\
\text { data }\end{array}$} & \multicolumn{5}{|c|}{ SNR value for each preprocessing test scenario } \\
\cline { 2 - 6 } & Canny & $\begin{array}{l}\text { Median Blur } \\
\text { +Canny }\end{array}$ & $\begin{array}{l}\text { Sharp } \\
\text { Canny }\end{array}$ & $\begin{array}{l}\text { Median Blur } \\
+ \text { Sharp + } \\
\text { Canny }\end{array}$ & $\begin{array}{l}\text { Sharp + Median } \\
\text { Blur + Canny }\end{array}$ \\
\hline Image 1 & $17.828 \mathrm{db}$ & $20.6652 \mathrm{db}$ & $10.7621 \mathrm{db}$ & $15.1093 \mathrm{db}$ & $15.2612 \mathrm{db}$ \\
\hline Image 2 & $18.5102 \mathrm{db}$ & $20.8102 \mathrm{db}$ & $12.4115 \mathrm{db}$ & $15.3203 \mathrm{db}$ & $16.854 \mathrm{db}$ \\
\hline Image 3 & $20.6562 \mathrm{db}$ & $22.1799 \mathrm{db}$ & $12.0546 \mathrm{db}$ & $16.6861 \mathrm{db}$ & $18.174 \mathrm{db}$ \\
\hline
\end{tabular}

The five scenarios above are conducted by using OpenCV library, then calculating Signal to Noise Ratio (SNR) to get quality of preprocessing. SNR is a value that shows the image quality, and this analysis is to determine which image is the best effect of the noise [7]. In this research, SNR calculation is calculated using matlab. First, selecting ten random data, then each data is processed by edge detection in accordance with the proposed preprocessing test, then the image edge detection results are inserted into the matlab application to calculate SNR values. The higher SNR value indicates that the image quality improves [8]. SNR calculation results for ten sample data are shown in Table 3. Based on the SNR calculation results obtained the conclusion that scenario two (median blur and canny) produce the best preprocessing and image detection. Image comparison of edge detection results of each preprocessing test scenario is shown in Figure 1.

IJCCS Vol. 13, No. 2, April 2019: $105-116$ 


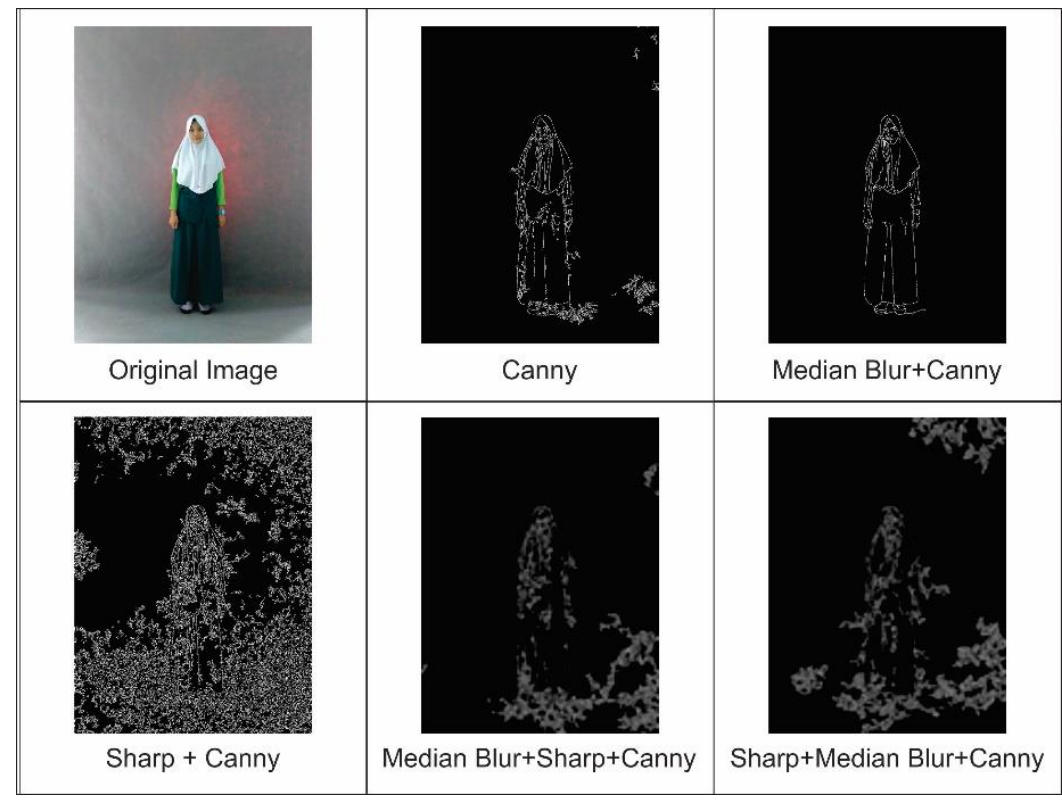

Figure 1 Image Comparison of Edge Detection

6. Proposed algorithm for calculation of height and width of object in image

At this stage some algorithms are proposed to calculate the height and width of the object in the image, then the calculation result of each algorithm is compared to get the best algorithm. To determine the approximate height and weight of an object that is in the image, then it needs an algorithm that can be used to calculate the width and height of objects in the image. The value of the width and height of this object is used to calculate the estimated weight of the object by applying a combination formula between the formula of tube and the formula of body surface area. Here is the proposed algorithm for calculating the height of object as shown in Figure 2.

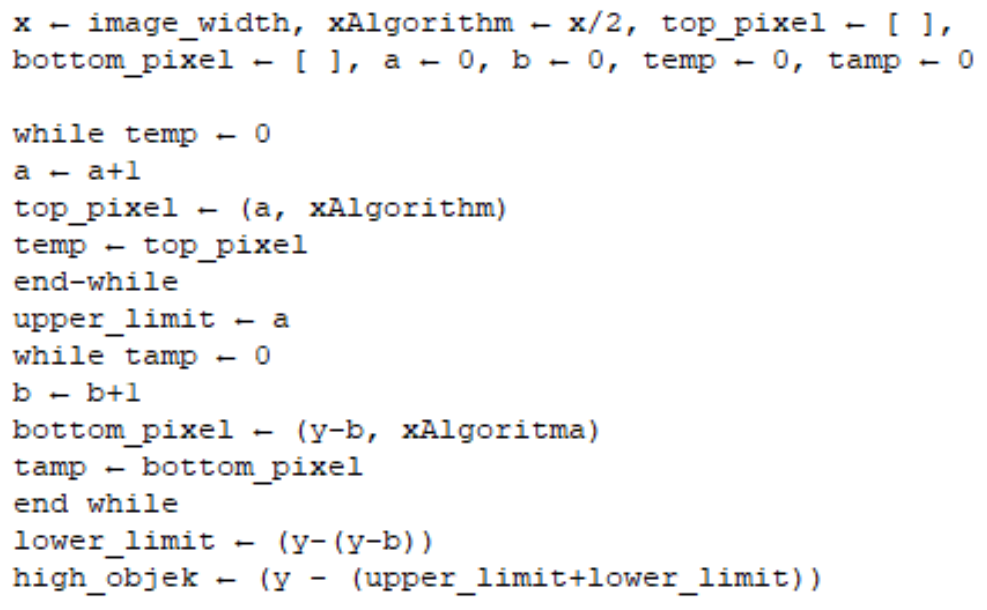

Figure 2 Pseudocode for calculating height of object

Here are some algorithms proposed by the researcher:

A. Algorithm A (Searches from half image width and image height)

The calculation to determine the height of the object starts from half of the width of the image in which each is performed from the top edge and the lower edge starting from the edge 
of the image then moving inward until it finds the edges of the object. Then from half of the height of each image from the left edge and the right edge of the image then moves inward until it finds the edge of the object to obtain the width of the object. The illustration of algorithm A as shown in Figure 3.

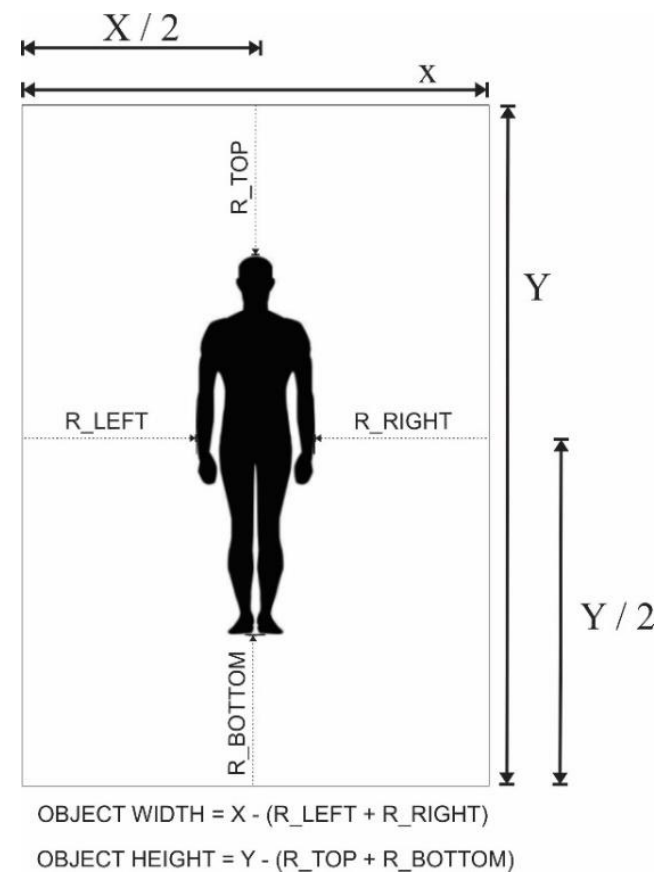

Figure 3 The illustration of algorithm A

Pseudocode calculates the width of the object with algorithm A as shown in Figure 4:

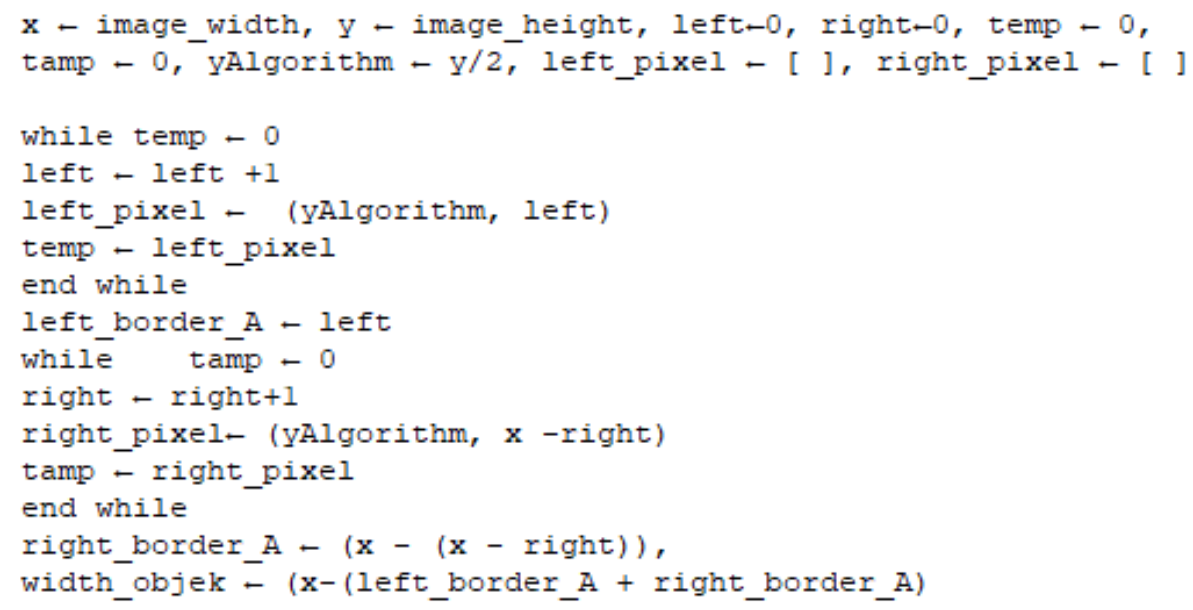

Figure 4 Pseudocode to calculate width of object with algorithm A

B. Algorithm B (Searches from half of the image width and height of the shoulders)

The calculation to determine the height of the object in algorithm $\mathrm{B}$ is equal to the calculation to determine the height of the object in algorithm A. To determine the width of the object starts from an image position that adjusts to the shoulder height of an object that exists within the image. Based on the average calculation of result of shoulder height from the foot, it obtained the value of shoulder height amounted 0.743 (height $=0.743 *$ object_height ). The illustration of algorithm B as shown in Figure 5. 


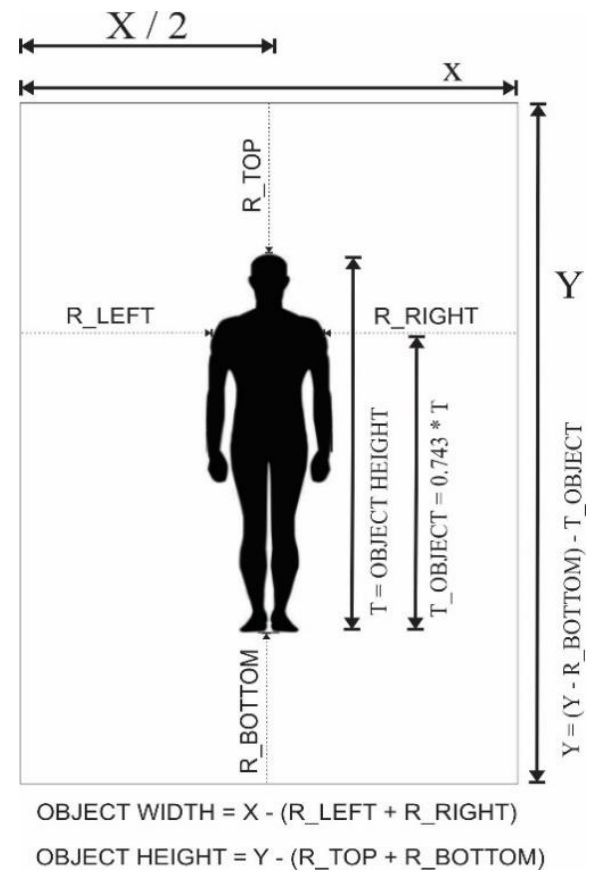

Figure 5 The illustration of algorithm $B$

Pseudocode calculates the width of the object with algorithm B as shown in Figure 6.

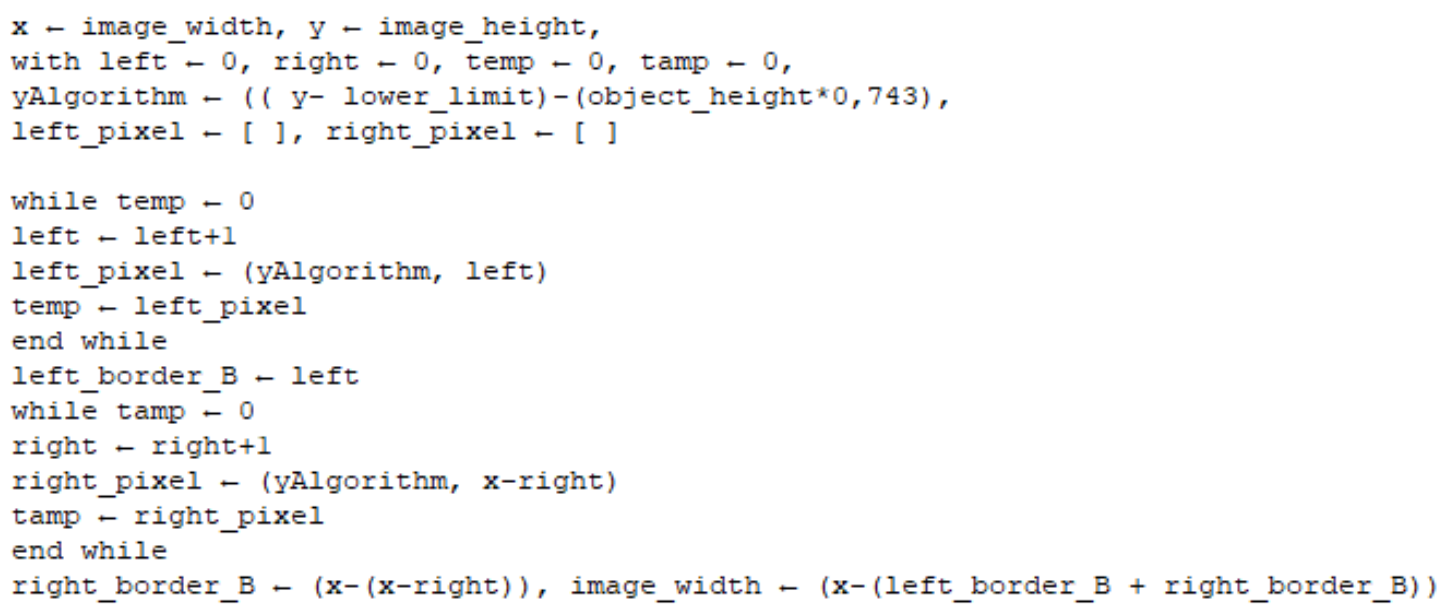

Figure 6 Pseudocode to calculate width of object with algorithm B

C. Algorithm C (Searches from half of the image width and height of the object)

The calculation to determine the height of the object in algorithm $\mathrm{C}$ is equal to the calculation to determine the height of the object in algorithm A. To determine the width of the object starts from the position of the image that adjusts half of the height of the object in the image (height $=0,5 *$ object_height). The illustration of algorithm $\mathrm{C}$ is shown in Figure 7. 


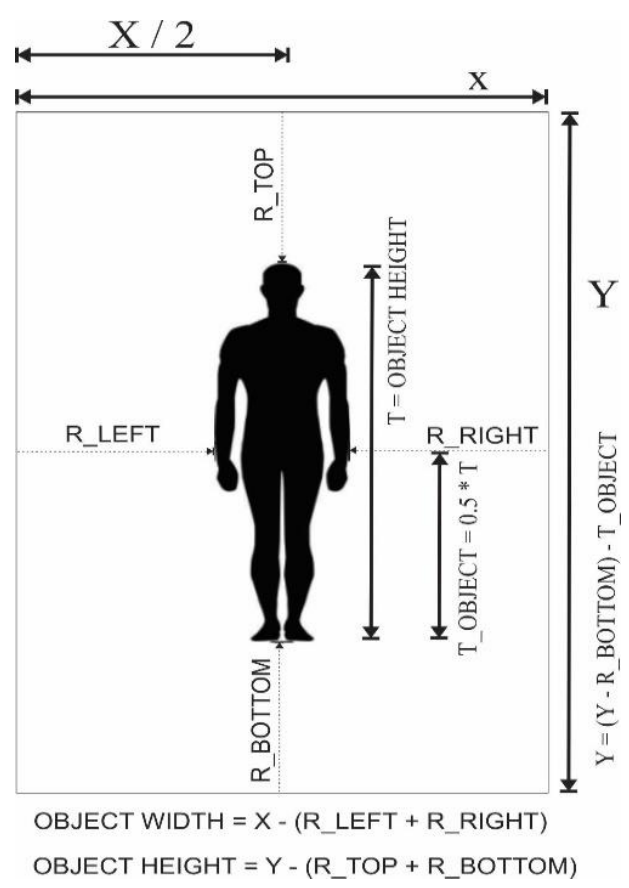

Figure 7 The illustration of algorithm C

Pseudocode calculates the width of the object with algorithm $\mathrm{C}$ as shown in Figure 8.

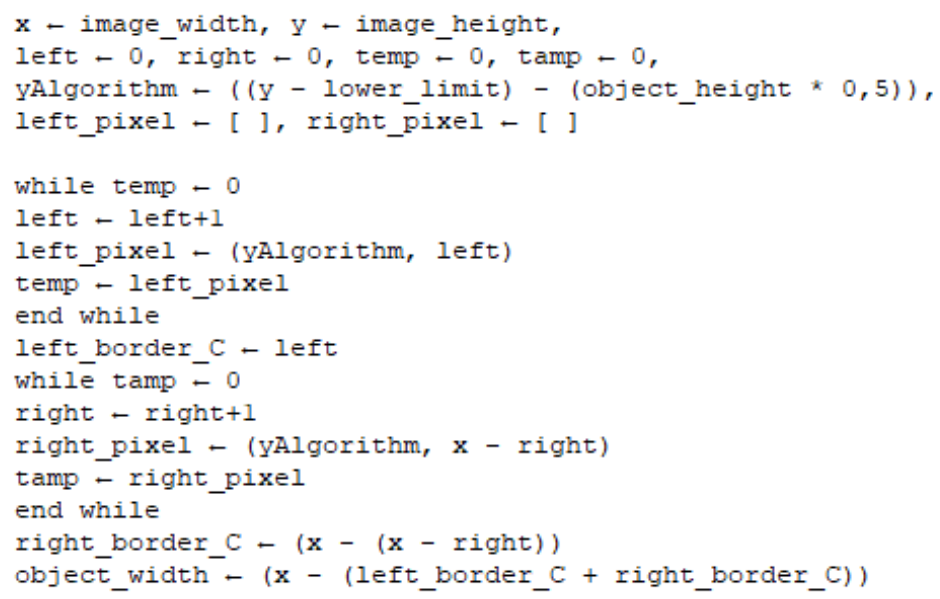

Figure 8 Pseudocode to calculate the width of object with algorithm C

D. Algorithm D (searches from half of the image width and $2 / 3$ of the object height)

The calculation to determine the height of the object in algorithm $\mathrm{D}$ is equal to the calculation to determine the height of the object in algorithm A. To determine the width of the object starts from the position of the image that adjusts $2 / 3$ of the height of the object in the image (height $=(2 *$ object_height $) / 3)$. The illustration of algorithm D is shown in Figure 9. 


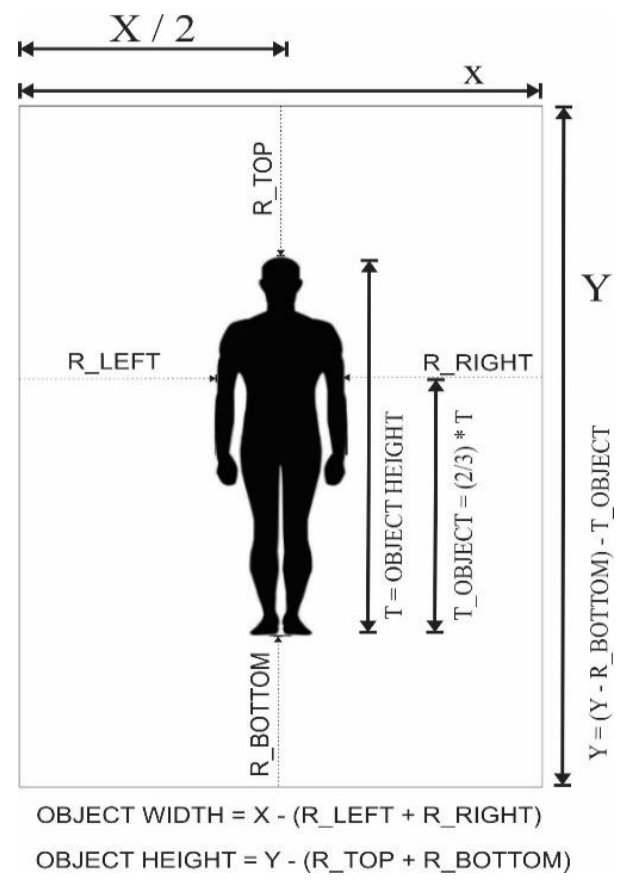

Figure 9 The illustration of algorithm D

Pseudocode calculates the width of the object with algorithm D as shown in Figure 10.

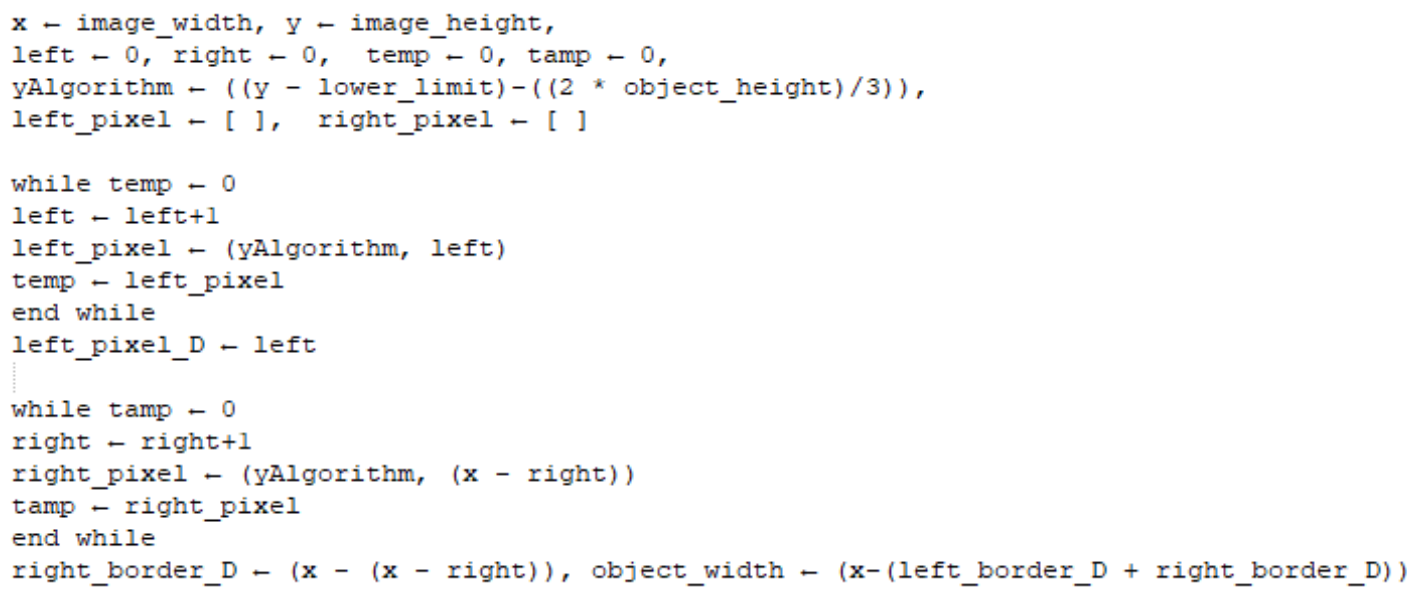

Figure 10 Pseudocode to calculate the width of object with algorithm D

7. Determination of ideal body weight using Body Mass Index Formula

Body mass index (BMI) is a common matrix used today to define the height or weight characteristics of adult anthropometry and to classify them into groups [9]. BMI is the index of heavy anthropometry and height of human body expressed as weight (in kilograms) divided by height (in squared meters) [10]. BMI value can be calculated using formula (9).

BMI $=\frac{\text { Weight }(\mathrm{kg})}{\text { (Height }(\mathrm{m}))^{2}}$

The BMI value using the formula is then matched with the standard BMI value table to determine the classification of a persons body. Standard BMI score tables for men and women are shown in Table 4. 
Table 4 Standard BMI Male and Female

\begin{tabular}{|l|c|l|c|}
\hline \multicolumn{1}{|c|}{ Male } & \multicolumn{2}{c|}{ Female } \\
\hline BMI Score & Category & Category \\
\hline Less than 17 & Thin & Less than 18 & Thin \\
\hline $23-22,9$ & Ideal & $18-24,9$ & Ideal \\
\hline 27 or more & Fat & $25-26,9$ & Fat \\
\hline
\end{tabular}

\section{Testing and System Analysis}

After being successfully implemented on android device, then the system is tested using some photos of human body. Based on the test results, the level of accuracy of the system in determining the classification of ideal body weight can be found.

\section{RESULTS AND DISCUSSION}

This stage shows the results of the calculation of the height and weight and the comparison of the accuracy of the weight categories of each algorithm that has been proposed. There are several formulas that will be used to calculate the difference and the percentage of deviation in the height and weight as shown by formulas 10,11, 12, and 13 .

Height difference $=$ |actual height - algorithm height $\mid$
Height deviation $=\frac{\text { |actual height }- \text { algorithm height } \mid}{\text { actual height }} \times 100 \%$
Weight difference $=$ |actual weight - algorithm weight $\mid$
Weight deviation $=\frac{\text { |actual weight }- \text { algorithm weight } \mid}{\text { actual weight }} \times 100 \%$

This is the result of the calculation of each proposed algorithm :

After the object height and object width are obtained by algorithm A, then the BSA can be calculated by Formula (3). then the formula (7) is used to get the weight value, while the Formula (6) is used to get the height values. Furthermore, to determine the ideal body weight, use the calculation of Body Mass Index (BMI) according to formula (9). The results of the calculation of ideal body weight algorithm are compared with the table of standard BMI for women and men in Table 4, while the calculation of the actual ideal body weight uses the conventional formula in formula (1). Sample data from the calculation of Algorithm A are shown in Table 5.

Table 5 Sample data from the calculation of Algorithm A

\begin{tabular}{|c|c|c|c|c|c|c|c|c|c|c|c|}
\hline \multicolumn{10}{|c|}{ Algorithm A } \\
\hline No. & Name & TB_Ss & BB_Ss & $\begin{array}{l}\text { TB_A } \\
\mathbf{l}\end{array}$ & $\begin{array}{l}\text { BB_A } \\
\mathbf{l}\end{array}$ & $\mathbf{S T}$ & $\mathbf{S B}$ & $\begin{array}{l}\text { Py_T } \\
\mathbf{B}\end{array}$ & Py_BB & KB_Sb & KB_Al \\
\hline 1. & Ardi & 167 & 58 & 165 & 69 & 2 & 11 & 1,19 & 18,9 & Ideal & Fat \\
\hline 2. & Fahrul & 166 & 49 & 165 & 53 & 1 & 4 & 0,60 & 8,16 & Ideal & Ideal \\
\hline$\ldots$ & $\ldots$ & $\ldots$ & $\ldots$ & $\ldots$ & $\ldots$ & $\ldots$ & $\ldots$ & $\ldots$ & $\ldots$ & $\ldots$ & $\ldots$ \\
\hline 46. & Selfira & 155 & 37 & 151 & 33 & 4 & 4 & 2,58 & 10,81 & Thin & Thin \\
\hline 47. & Riski & 177 & 76 & 181 & 82 & 4 & 6 & 2,25 & 7,89 & Fat & Fat \\
\hline \multicolumn{19}{|c|}{ Difference average } & & $\mathbf{3 , 0 2}$ & $\mathbf{7}$ & $\mathbf{1 , 8 5}$ & $\mathbf{1 2 , 9 4}$ & & \\
\hline
\end{tabular}

Information:

TB_Sb $=$ Actual height $(\mathrm{cm})$
TB_Al $=$ Algorithm height $(\mathrm{cm})$
ST $=$ Height difference $(\mathrm{cm})$
Py_TB $=$ Height deviation $(\%)$
KB_Sb $=$ Actual weight category

BB_Sb $=$ Actual weight $(\mathrm{kg})$

BB_Al = Algorithm weight $(\mathrm{kg})$

$\mathrm{SB} \quad=$ Weight difference $(\mathrm{kg})$

Py_BB $=$ Weight deviation $(\%)$

$\mathrm{KB} \_\mathrm{Al}=$ Algorithm weight category

IJCCS Vol. 13, No. 2, April 2019 : $105-116$ 
Then, the level of system accuracy is calculated by the Confusion Matrix as show in Table 6 .

Table 6 Calculation of Confusion Matrix Algorithm A

\begin{tabular}{|c|c|c|c|c|c|c|}
\hline & & \multicolumn{4}{|c|}{ True } & \multirow{2}{*}{ Class Precission } \\
\hline & & Thin & Ideal & Fat & Obese & \\
\hline \multirow{4}{*}{ Predict } & Thin & 4 & 4 & 0 & 0 & $50 \%$ \\
\hline & Ideal & 6 & 16 & 1 & 0 & $69,56 \%$ \\
\hline & Fat & 0 & 3 & 4 & 2 & $44,44 \%$ \\
\hline & Obese & 0 & 2 & 1 & 4 & $57,14 \%$ \\
\hline \multicolumn{2}{|l|}{ Recall } & $40 \%$ & $64 \%$ & $66,67 \%$ & $66,67 \%$ & \\
\hline
\end{tabular}

Accuracy $=\left(\frac{4+16+4+4}{((4+4+0+0)+(6+16+1+0)+(0+3+4+2)+(0+2+1+4))}\right) x 100$

Accuracy $=(28 / 47) \times 100=59,57 \%$. Based on the calculation of Confusion Matrix Algorithm $\mathrm{A}$, the value of accuracy is $59.57 \%$. The same calculation is applied to the other three proposed algorithms, Algorithm B, Algorithm C, and Algorithm D. So that a comparison of the calculations from each algorithm is shown in Table 7.

Table 7 Comparison of the calculation of each algorithm

\begin{tabular}{|c|c|c|c|c|}
\hline No. & Algorithm name & Deviation of height & Deviation of weight & Accuracy \\
\hline 1. & Algorithm A & $1,85 \%$ & $12,94 \%$ & $59,57 \%$ \\
\hline 2. & Algorithm B & $1,85 \%$ & $10,7 \%$ & $61,7 \%$ \\
\hline 3. & Algorithm C & $1,85 \%$ & $8,87 \%$ & $78,7 \%$ \\
\hline 4. & Algorithm D & $1,85 \%$ & $16,79 \%$ & $61,7 \%$ \\
\hline
\end{tabular}

Based on the data shown in table 6 , the conclusion can be obtained that the algorithm $\mathrm{C}$ by using the multiplier factor $(k=1,0023)$ is the the best proposed algorithm to determine the ideal body weight. The calculation of ideal body weight using algorithm $\mathrm{C}$ has a value of deviation 1,85 against height and $8,87 \%$ against body weight and has accuracy of $78,7 \%$. Therefore, algorithm $\mathrm{C}$ is defined as the algorithm to be used in system calculation.

\section{CONCLUSIONS}

Based on the results of research, the researchers have managed to implement an algorithm that can be used to calculate the weight and height of a person based on his human body image captured from an android smartphone camera so that it can be used to classify human weight based on four classes those are thin, ideal, fat, and obese. The best proposed algorithm is the algorithm $\mathrm{C}$, which calculates the width of the object starting from the position of the image that adjusts to half of the height of the human object in the image using the multiplier factor value $(\mathrm{k})$ of 1.0023 obtained value of relative of deviation of $1.87 \%$ of the height and $8.87 \%$ of the weight. While the level of accuracy of the system in classifying the ideal body weight category has reached $78.7 \%$ of the actual ideal weight category. So that algorithm $\mathrm{C}$ will be used as a calculation algorithm in the development of digital image processing system in mobile android applications that can be used for the classification of the ideal body weight based on images.

\section{REFERENCES}

[1] A. Mustafid and S. 'Uyun. "Segmentasi Citra Sapi Berbasis Deteksi Tepi Menggunakan Algoritma Canny Edge Detection”, Jurnal Buana Informatika, vol. 8, no. 1, pp. 27-36, (2017)[online]. Available : https://ojs.uajy.ac.id/index.php/jbi/article/view/1074. [Accessed: 08-Feb-2019]. 
[2] A. Mustafid and S. 'Uyun. "Sistem Pengolahan Citra Digital untuk Menentukan Bobot Sapi Menggunakan Metode Titik Berat", Jurnal Teknologi Informasi dan Ilmu Komputer (JTIIK), vol.5, no.6, pp. 677-685, Nov. 2018[online]. Available: http://jtiik.ub.ac.id/index.php/jtiik/article/view/841/pdf. [Accessed: 08-Feb-2019].

[3] F. R. M. Trisno, R. D. Atmaja, and H. Fauzi, "Perancangan Sistem Pengukuran Berat Badan dengan Image Processing", e-Proceeding of Engineering, vol . 3, no. 2, Augst. 2016[online]. Available https://openlibrary.telkomuniversity.ac.id/pustaka/ 116805/perancangan-sistem pengukuran-berat-badan-dengan-image-processing.html. [Accessed: 28-Des-2017].

[4] T. Efendi, I. I. Uljannah, and T. A. Tsauri, "Rancang Bangun Sistem Pengolahan Citra Digital untuk Menentukan Berat Badan Ideal", JISKA(Jurnal Informatika UIN Sunan Kalijaga Yogyakarta), vol. 2, no. 2, Sept. 2017[online]. Available: https:// http://ejournal.uin-suka.ac.id/saintek/JISKA/article/view/1123/1058. [Accessed: 28-Des-2017].

[5] Rianto, P. Rianto and A. Harjoko, "Penentuan Kematangan Buah Salak Pondoh Di Pohon Berbasis Pengolahan Citra Digital”. IJCCS (Indonesian Journal of Computing and

Cybernetics Systems), vol.11, No.2, July. 2017, pp. 143-154[online]. Available: https:// jurnal.ugm.ac.id/ijccs/article/viewFile/17416/16693. [Accessed: 28-Des-2017].

[6] H. Bipembi, J. K. Panford, and O. Appiah, "Calculation of Body Mass Index using Image Processing Techniques", IJAIM(International Journal of Artificial Intellegence and Mechantonics), vol 4, issues 1, July.2015[online]. Available: https://www.ijaim.org/vol issues.html?view=publication\&task=show\&id=130. [Accessed: 27-Des-2017].

[7] M.B. Murinto, "Analisis Perbandingan Metode 2d Median Filter dan Multilevel Median Filter pada Proses Perbaikan Citra Digital", Jurnal Informatika, vol. 6, no. 2, July. 2012[online]. Available: http://journal.uad.ac.id/index.php/JIFO/article/view/2778. [Accessed: 28-Des-2017].

[8] S. Bahri, "Aplikasi Perbaikan Kualitas Citra Menggunakan Contrast Stretching untuk Mengetahui Akurasi Face Recognition pada Sistem Monitoring Ruagan Berbasis Webcam", 2015, Skripsi Universitas Islam Negeri Maulana Malik Ibrahim Malang.Available: http://etheses.uin-malang.ac.id/8162/1/09650207.pdf. [Accessed: 28Des-2017].

[9] N. Frank Q, "Body Mass Index: Obesity, BMI, and Health: Critical Review”. LWW Journals, volume 50, Number 3, May/June 2015 [online]. Available: https://journals.lww.com/nutritiontodayonline/Fulltext/2015/05000/Body_Mass_Index _ _Obesity,_BMI,_and_Health_A.5.aspx. [Accessed: 07-Apr-2018].

[10] M. Sperrin, dkk. "Body mass index relates weight to height differently in women and older adults: serial cross-sectional surveys in England (1992-2011)". Journal of Public Health, vol. 38, No.3, pp. 607 - 613, June 1, 2015 [online]. Available: https://www.ncbi.nlm.nih.gov/pmc/articles/PMC5072155/pdf/fdv067.pdf. [Accessed:07-Apr-2018]. 